\title{
Association between TNF- $\alpha$ rs1800629 polymorphism and the risk of myocardial infarction: A meta-analysis
}

\author{
X.P. Hua ${ }^{1 *}$, J. Qian ${ }^{1 *}$, C.B. Cao ${ }^{1 *}$, J. Xie ${ }^{1}$, X.T. Zeng ${ }^{2}$ and Z.J. Zhang ${ }^{1}$ \\ ${ }^{1}$ Department of Cardiology, Suizhou Central Hospital, \\ Affiliated Hospital of Hubei University of Medicine, Suizhou, \\ Hubei Province, China \\ ${ }^{2}$ Center for Evidence-Based and Translational Medicine, \\ Zhongnan Hospital of Wuhan University, Wuhan, Hubei Province, China \\ *These authors contributed equally to this study. \\ Corresponding author: Z.J. Zhang \\ E-mail: zhangzhenjian001@163.com
}

Genet. Mol. Res. 15 (3): gmr. 15037292

Received September 14, 2015

Accepted November 19, 2015

Published August 29, 2016

DOI http://dx.doi.org/10.4238/gmr.15037292

Copyright (C) 2016 The Authors. This is an open-access article distributed under the terms of the Creative Commons Attribution ShareAlike (CC BY-SA) 4.0 License.

ABSTRACT. The tumor necrosis factor-alpha (TNF- $\alpha$ ) G-308A polymorphism has been suggested to be a susceptibility factor for myocardial infarction (MI). However, differing results from various studies have led to controversial conclusions. Hence, we performed a meta-analysis to evaluate the association between TNF- $\alpha$ G-308A polymorphism and MI. Reported studies published before March 30, 2015 were included and analyzed from the PubMed and Embase databases. Study selection and data extraction were carried out independently by two authors. The odds ratios (ORs) and 95\% confidence intervals (CIs) were used to evaluate the association between the selected variables using the Comprehensive Meta-Analysis v2.2 software. In total, 12 publications with 13 case-control studies consisting of 6037 cases and 7262 controls 
were included in our meta-analysis. The overall results showed that there was no significant association between TNF- $\alpha$ G-308A polymorphism and $\mathrm{MI}$ risk $[\mathrm{A} v s \mathrm{G}$ : $\mathrm{OR}=1.18,95 \% \mathrm{CI}=0.94-1.48$; $\mathrm{AA} v s \mathrm{GG}$ : $\mathrm{OR}=$ $1.23,95 \% \mathrm{CI}=0.74-2.05$; GA $v s \mathrm{GG}: \mathrm{OR}=1.22,95 \% \mathrm{CI}=0.98-1.51$; $(\mathrm{GA}+\mathrm{AA}) v s \mathrm{G}: \mathrm{OR}=1.21,95 \% \mathrm{CI}=0.96-1.54$; $\mathrm{AA} v s(\mathrm{GG}+\mathrm{GA}): \mathrm{OR}$ $=1.16,95 \% \mathrm{CI}=0.72-1.88]$. However, when subgroup analysis was performed according to the stages of MI, results indicated that there was a significant association between TNF- $\alpha$ G-308A polymorphism and the risk of acute MI. Other subgroup analyses revealed no significant associations. Current evidence suggests that TNF- $\alpha$ G-308A polymorphism may be associated with increased risk for acute MI.

Key words: Tumor necrosis factor-alpha; Polymorphism; Myocardial infarction; Acute myocardial infarction; Meta-analysis

\section{INTRODUCTION}

Myocardial infarction (MI), commonly known as a heart attack, occurs as a result of necrosis of the heart muscle due to prolonged ischemia, and is a clinical manifestation of coronary artery disease (Rich, 2006). The etiology of MI is complex, and involves interactions between genetic and environmental factors (Marenberg et al., 1994; Schunkert et al., 2010; Leng et al., 2015). Diabetes mellitus (Sattar, 2013), obesity (Yatsuya et al., 2010), psychological factors (Edmondson et al., 2013), and smoking (Meyers et al., 2009) are all associated with increased risk of MI. These factors act in concert with the multiple inherited genetic variants (Olivieri et al., 2006; Schunkert et al., 2010; Suo et al., 2015) that may lead to onset of MI.

Tumor necrosis factor-alpha (TNF- $\alpha$ ) is a key pro-inflammatory factor which has been associated with several human diseases (Cheng et al., 2013; Song et al., 2013; Zhuang et al., 2013). The TNF- $\alpha$ gene is located in the major histocompatibility complex III region on chromosome 6p21.3. G-238A (rs361525), G-308A (rs1800629), and C-857T (rs1799724) are the commonly studied single nucleotide polymorphisms in the TNF- $\alpha$ gene (Falvo et al., 2010). In 1998, Herrmann et al. (1998) first reported that the TNF- $\alpha$ G-308A polymorphism is unlikely to contribute to increased MI risk. However, case-control studies, which followed this first hypothesis yielded inconsistent results. Therefore, it is still unknown whether there is a significant association between TNF- $\alpha$ G-308A polymorphism and MI risk. In this study, we performed a meta-analysis to estimate the overall effect of TNF- $\alpha$ G-308A polymorphism on the risk of MI, and whether MI risk is influenced by ethnicity.

\section{MATERIAL AND METHODS}

We performed this meta-analysis according to the proposal laid out by the PRISMA (preferred reporting items for systematic reviews and meta-analyses) statement (Moher et al., 2009).

\section{Eligibility criteria}

A study was considered eligible if it met all of the following criteria: 1) the study followed a case-control design, 2) the study investigated the association between TNF- $\alpha$ 
G-308A polymorphism and MI susceptibility, 3) only MI patients without other systemic diseases such as diabetes mellitus were included as cases; all controls were healthy subjects without cardiovascular illnesses; both cases and controls were clearly diagnosed, and 4) the study included information that allowed for calculation of the odds ratios (ORs) and $95 \%$ confidence intervals (CIs). If any publication involved the same subjects, the more comprehensive study was chosen.

\section{Literature search}

The PubMed and Embase databases were searched for relevant studies that were published up to May 30, 2015. The search strategy included usage of the following key words: "myocardial infarction", "myocardial infarct", "polymorphism", "mutation", "variant", "tumor necrosis factor", and "TNF". Moreover, we also searched through the references cited in the selected articles and reviews to recruit additional relevant studies. Publication language for the selected studies was restricted to either English or Chinese. The literature search was conducted by two independent authors, who evaluated the eligibility of all studies. Disagreements were resolved by discussions.

\section{Data extraction}

The first author's last name, publication year, country of origin, ethnicity, sources of controls and matching criteria, sample sizes of cases and controls, genotype distribution in cases and controls, Hardy-Weinberg equilibrium (HWE) for controls, and genotyping methods were independently extracted from all eligible studies by the two authors. HWE was assessed by the chi-square test, and significance was set at $\mathrm{P}<0.05$. Disagreements were resolved by discussions.

\section{Data analysis}

All analyses were conducted using the Comprehensive Meta-Analysis v2.2 software (Zeng et al., 2015b). The ORs and its $95 \%$ CIs were used to evaluate the pooled and single effect size to determine whether there was a significant association between cases and controls. Heterogeneity was evaluated using the $R^{2}$ test, and homogeneity was defined as when the $I^{2}$ value was smaller than $25 \%$ (Higgins et al., 2003). If no heterogeneity was found, the fixedeffect model was used; otherwise, the random-effect model was used. Subgroup analysis was conducted according to ethnicity, source of control, stages of MI (old, acute or both), and HWE to investigating the differences between these factors, and whether one of them contributed to significant heterogeneity. Sensitivity analysis was performed to investigate the influence of a single study on overall analysis, and to test the robustness of overall results. Potential publication bias was assessed by visual inspection of funnel plots and the Egger test (Mao et al., 2013; Zeng et al., 2015b). Five genetic models were used for overall and subgroup analyses (Suo et al., 2015; Zeng et al., 2015b): A vs G, AA vs GG, AG vs GG, (AG+AA) vs GG, and AA vs (AG+GG).

\section{RESULTS}

\section{Study identification}

Of the 147 initially identified studies, 12 publications with 13 case-control studies 
were included in our analysis (Herrmann et al., 1998; Padovani et al., 2000; Koch et al., 2001; Tobin et al., 2004; Bennet et al., 2006; Hou et al., 2009; Ghaderian et al., 2011; Zeybek et al., 2011; Chu et al., 2012; Szabó, 2013; Vaccarino et al., 2013; Biswas et al., 2014). Figure 1 shows a detailed flowchart of the selection process.

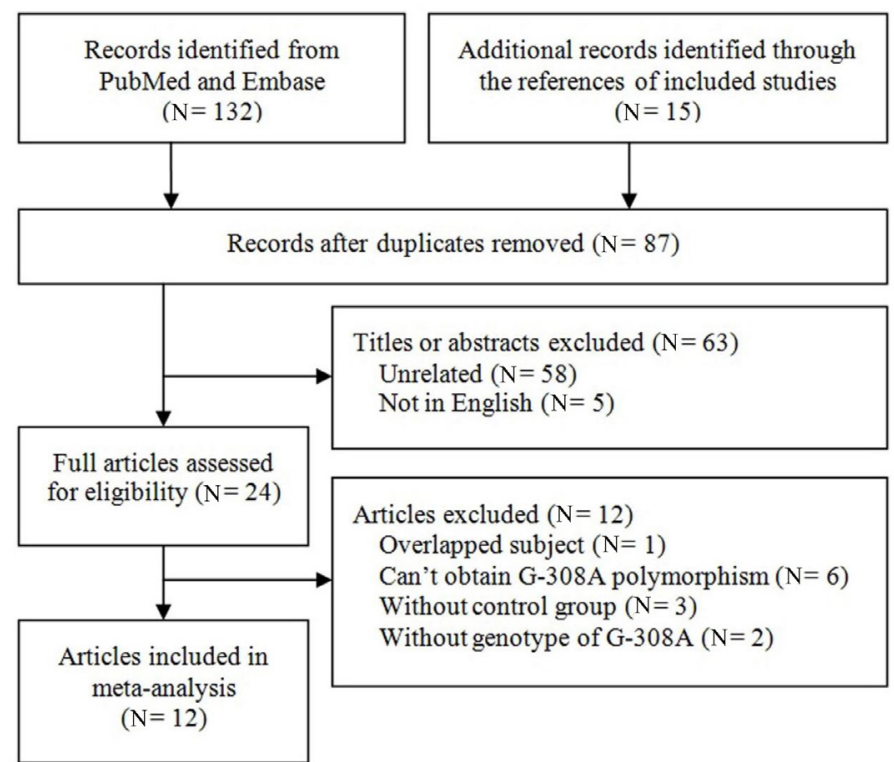

Figure 1. Flow chart of the study section process.

\section{Study characteristics}

Thirteen case-control studies published in English, which included 6037 MI patients and 7262 controls, were chosen for this meta-analysis. Of those studies, one was a multiple-center study, and consisted of two case-control studies (Herrmann et al., 1998), while all others were single-center studies. Three studies investigated acute myocardial infarction (AMI) patients only (Ghaderian et al., 2011; Vaccarino et al., 2013; Biswas et al., 2014), while the other 10 case-control studies included mixed patients at varying stages of the disease (old, recent, or acute). All studies reported the genotype frequencies of cases and controls. In the selection of control subjects, 8 studies were population-based (Herrmann et al., 1998; Padovani et al., 2000; Koch et al., 2001; Bennet et al., 2006; Chu et al., 2012; Vaccarino et al., 2013; Biswas et al., 2014), and 5 were hospital-based (Tobin et al., 2004; Hou et al., 2009; Ghaderian et al., 2011; Zeybek et al., 2011; Szabó et al., 2013). The genotype distributions of the controls in the 9 studies (Herrmann et al., 1998; Padovani et al., 2000; Koch et al., 2001; Tobin et al., 2004; Bennet et al., 2006; Hou et al., 2009; Chu et al., 2012; Vaccarino et al., 2013) were in accordance with the HWE, while that of the remaining 4 studies deviated from the HWE (Ghaderian et al., 2011; Zeybek et al., 2011; Szabó et al., 2013; Biswas et al., 2014). Table 1 presents the major characteristics of the 13 case-control studies. 
Table 1. Major characteristics of 12 case-control studies included in the meta-analysis.

\begin{tabular}{|c|c|c|c|c|c|c|c|c|c|}
\hline \multirow[t]{2}{*}{ References } & \multirow[t]{2}{*}{ Country (Ethnicity) } & \multirow[t]{2}{*}{ Endpoint } & \multirow{2}{*}{$\begin{array}{c}\text { Sample } \\
\text { size } \\
(\mathrm{Ca} / \mathrm{Co})\end{array}$} & \multicolumn{3}{|c|}{ Genotype distribution $(\mathrm{Ca} / \mathrm{Co})$} & \multirow{2}{*}{$\begin{array}{c}\text { Source } \\
\text { of } \\
\text { control }\end{array}$} & \multirow{2}{*}{$\begin{array}{l}\text { Genotypin } \\
\text { g method }\end{array}$} & \multirow[t]{2}{*}{ HWE } \\
\hline & & & & GG & GA & AA & & & \\
\hline Herrmann et al. (1998) & $\begin{array}{l}\text { Northern Ireland } \\
\text { (Caucasian) }\end{array}$ & Mixed & $196 / 176$ & $117 / 97$ & $63 / 73$ & $16 / 6$ & PB & $\begin{array}{l}\text { PCR- } \\
\text { SSCP }\end{array}$ & Yes \\
\hline Herrmann et al. (1998) & France (Caucasian) & Mixed & $445 / 534$ & $325 / 376$ & $113 / 148$ & $7 / 10$ & PB & $\begin{array}{l}\text { PCR- } \\
\text { SSCP }\end{array}$ & Yes \\
\hline Padovani et al. (2000) & Brazil (Caucasian) & Mixed & $148 / 148$ & $120 / 114$ & $26 / 33$ & $2 / 1$ & PB & PCR & Yes \\
\hline Koch et al. (2001) & Germany (Caucasian) & Mixed & $793 / 340$ & $565 / 244$ & $215 / 83$ & $13 / 13$ & PB & PCR & Yes \\
\hline Tobin et al. (2004) & UK (Caucasian) & Mixed & $547 / 505$ & $365 / 337$ & $163 / 146$ & $19 / 22$ & HB & PCR & Yes \\
\hline Bennet et al. (2006) & Sweden (Caucasian) & Mixed & $1167 / 1497$ & $799 / 1037$ & $340 / 412$ & $28 / 48$ & PB & PCR & Yes \\
\hline Hou et al. (2009) & China (Asian) & Mixed & $504 / 905$ & $439 / 802$ & $62 / 101$ & $3 / 2$ & HB & $\begin{array}{l}\text { PCR- } \\
\text { RFLP }\end{array}$ & Yes \\
\hline Ghaderian et al. (2011) & Iran (Caucasian) & AMI & $996 / 910$ & $681 / 717$ & $246 / 174$ & $69 / 19$ & $\mathrm{HB}$ & PCR & No \\
\hline Zeybek et al. (2011) & Turkey (Caucasian) & Mixed & $143 / 213$ & $76 / 166$ & $56 / 33$ & $11 / 14$ & HB & $\begin{array}{l}\text { PCR- } \\
\text { RFLP }\end{array}$ & No \\
\hline Chu et al. (2012) & China (Asian) & Mixed & $420 / 1020$ & $330 / 808$ & $87 / 205$ & $3 / 7$ & PB & PCR & Yes \\
\hline Szabó 2013 & Hungary (Caucasian) & Mixed & $118 / 384$ & $90 / 235$ & $26 / 108$ & $2 / 41$ & $\mathrm{HB}$ & PCR & No \\
\hline Vaccarino et al. (2013) & Italy (Caucasian) & AMI & $60 / 130$ & $38 / 111$ & $20 / 17$ & $2 / 2$ & PB & PCR & Yes \\
\hline Biswas et al. (2014) & India (Asian) & AMI & $500 / 500$ & $314 / 403$ & $123 / 68$ & $63 / 29$ & PB & PCR & No \\
\hline
\end{tabular}

$\mathrm{Ca}=$ case group; $\mathrm{Co}=$ control group; Mixed $=$ the stages of myocardial infarction that were missed; $\mathrm{AMI}=$ acute myocardial infarction; $\mathrm{PB}=$ population-based; $\mathrm{HB}=$ hospital-based; HWE = Hardy-Weinberg equilibrium.

\section{Meta-analysis}

Table 2 shows the overall and subgroup analyses as well as the heterogeneity test results. As substantial heterogeneity was detected using all 5 genetic models, we applied the randomeffect model to pool the data. The overall results did not show significant association between TNF- $\alpha$ G-308A polymorphism and MI susceptibility in any of the genetic models [A vs G: OR = $1.18,95 \% \mathrm{CI}=0.94-1.48, P^{2}=89 \%$; AA vs $\mathrm{GG}: \mathrm{OR}=1.23,95 \% \mathrm{CI}=0.74-2.05, I^{2}=78 \%$, Figure 2; GA $v s$ GG: $\mathrm{OR}=1.22,95 \% \mathrm{CI}=0.98-1.51, I^{2}=83 \%$; $(\mathrm{GA}+\mathrm{AA}) v s \mathrm{G}: \mathrm{OR}=1.21,95 \% \mathrm{CI}=$ $0.96-1.54, P^{2}=87 \%$; AA $v s(\mathrm{GG}+\mathrm{GA})$ : $\left.\mathrm{OR}=1.16,95 \% \mathrm{CI}=0.72-1.88, P^{2}=76 \%\right]$.

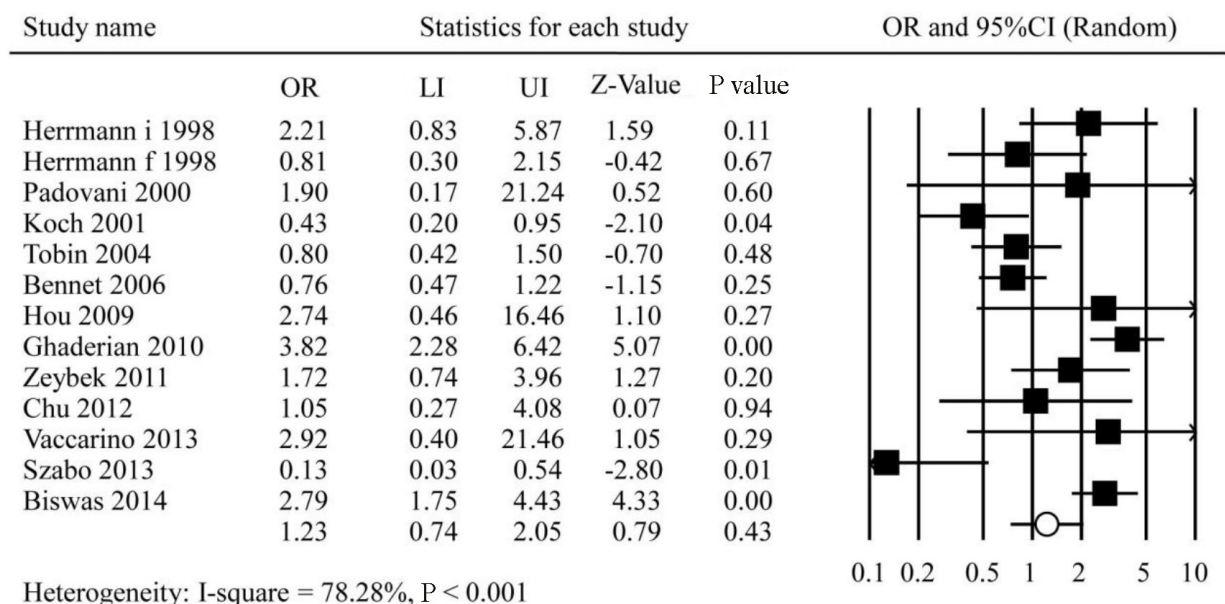

Decreased risk Increased risk

Figure 2. Forest plot of the results in AA vs GG comparison based on random-effect model. 
Table 2. ORs and 95\% CIs of overall and subgroup analyses.

\begin{tabular}{|c|c|c|c|c|c|c|c|c|c|c|c|}
\hline \multirow{2}{*}{$\begin{array}{l}\text { Total } \\
\text { and } \\
\text { Subgro } \\
\text { ups }\end{array}$} & \multirow{2}{*}{$\begin{array}{c}\text { Tria } \\
\text { 1s }\end{array}$} & \multicolumn{2}{|l|}{$\mathrm{A} v s \mathrm{G}$} & \multicolumn{2}{|l|}{ AA $v s$ GG } & \multicolumn{2}{|l|}{ GA $v s \mathrm{GG}$} & \multicolumn{2}{|c|}{$(\mathrm{GA}+\mathrm{AA}) v s \mathrm{GG}$} & \multicolumn{2}{|c|}{$\mathrm{AA} v s(\mathrm{GG}+\mathrm{GA})$} \\
\hline & & OR $(95 \% \mathrm{CI})$ & $\begin{array}{c}I^{2} \\
(\%)\end{array}$ & OR $(95 \% \mathrm{CI})$ & $\begin{array}{c}I^{2} \\
(\%)\end{array}$ & $\mathrm{OR}(95 \% \mathrm{CI})$ & $\begin{array}{c}I^{2} \\
(\%)\end{array}$ & OR $(95 \% \mathrm{CI})$ & $\begin{array}{c}I^{2} \\
(\%)\end{array}$ & OR $(95 \% \mathrm{CI})$ & $\begin{array}{c}I^{2} \\
(\%)\end{array}$ \\
\hline Total & 13 & $1.18(0.94-1.48)$ & 89 & $1.23(0.74-2.05)$ & 78 & $1.22(0.98-1.51)$ & 83 & $1.21(0.96-1.54)$ & 87 & $1.16(0.72-1.88)$ & 76 \\
\hline \multicolumn{12}{|c|}{ Ethnicity } \\
\hline Asian & 3 & $1.42(0.84-1.39)$ & 91 & $2.54(1.67-3.86)$ & 0 & $1.39(0.85-2.28)$ & 86 & $1.44(0.83-2.49)$ & 90 & $2.19(1.44-3.32)$ & 0 \\
\hline $\begin{array}{l}\text { Caucas } \\
\text { ian }\end{array}$ & 10 & $1.11(0.86-1.43)$ & 89 & $1.06(0.58-1.93)$ & 80 & $1.16(0.91-1.49)$ & 82 & $1.15(0.88-1.50)$ & 86 & $1.01(0.57-1.80)$ & 78 \\
\hline \multicolumn{12}{|c|}{ Source of control } \\
\hline PB & 8 & $1.18(0.90-1.54)$ & 87 & $1.21(0.66-2.23)$ & 73 & $1.16(0.89-1.52)$ & 81 & $1.19(0.89-1.57)$ & 85 & $1.17(0.66-2.05)$ & 69 \\
\hline HB & 5 & $1.17(0.74-1.840$ & 93 & $1.20(0.43-3.34)$ & 86 & $1.30(0.87-1.96)$ & 87 & $1.25(0.79-1.98)$ & 90 & $1.11(0.42-2.93)$ & 84 \\
\hline \multicolumn{12}{|c|}{ End point } \\
\hline AMI & 3 & $2.09(1.68-2.60)$ & 46 & $3.23(2.30-4.54)$ & 0 & $2.08(1.35-3.20)$ & 75 & $2.69(2.10-3.45)$ & 0 & $2.13(1.49-3.03)$ & 52 \\
\hline Mixed & 10 & $0.99(0.83-1.18)$ & 74 & $0.88(0.57-1.36)$ & 52 & $1.04(0.85-1.27)$ & 73 & $0.85(0.56-1.29)$ & 47 & $1.01(0.83-1.24)$ & 74 \\
\hline \multicolumn{12}{|l|}{ HWE } \\
\hline Yes & 9 & $1.02(0.91-1.14)$ & 39 & $0.87(0.65-1.16)$ & 24 & $1.03(0.89-1.20)$ & 50 & $1.03(0.89-1.18)$ & 44 & $0.92(0.63-1.36)$ & 31 \\
\hline No & 4 & $1.46(0.83-2.55)$ & 94 & $1.56(0.62-3.94)$ & 86 & $1.69(0.96-2.97)$ & 90 & $1.62(0.89-2.94)$ & 92 & $1.37(0.56-3.32)$ & 85 \\
\hline
\end{tabular}

$\mathrm{OR}=$ odds ratio $\mathrm{CI}=$ confidence interval; Mixed $=$ stages of myocardial infarction that were missed; $\mathrm{AMI}=$ acute myocardial infarction; $\mathrm{PB}=$ population-based; $\mathrm{HB}=$ hospital-based; HWE = Hardy-Weinberg equilibrium.

When we stratified the subgroups according to ethnicity, source of control, and HWE, we found similar results in the overall analysis of all 5 genetic models. However, we found significant association between TNF- $\alpha$ G-308A polymorphism and MI susceptibility in the AMI population. Substantial heterogeneity was detected in all subgroup analyses with the exception of some of the genetic models in the Asian population and the AMI group.

\section{Sensitivity analysis and publication bias}

Sensitivity analyses indicated that the overall results of all genetic models were robust, and were not influenced by any single study (Figure 3). Funnel plots were generated to assess publication bias in all 5 genetic models, and the shapes of the funnel plots were found to be symmetrical in all comparison models. Therefore, our results showed low risk of publication bias, which were further confirmed by the Egger test (Figure 4).

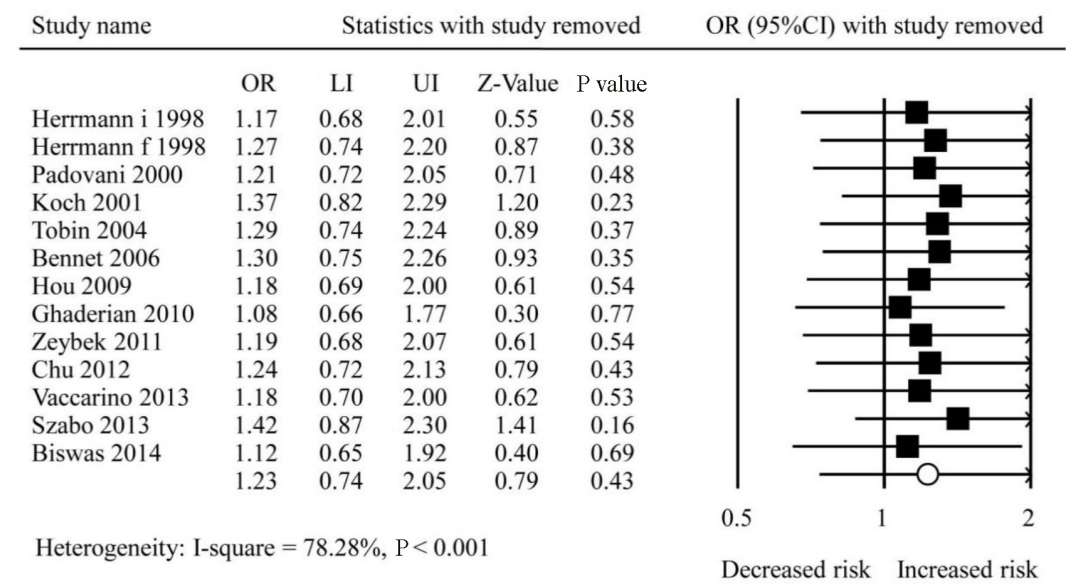

Figure 3. Forest plot of sensitivity analysis in AA vs GG comparison based on random-effect model. 


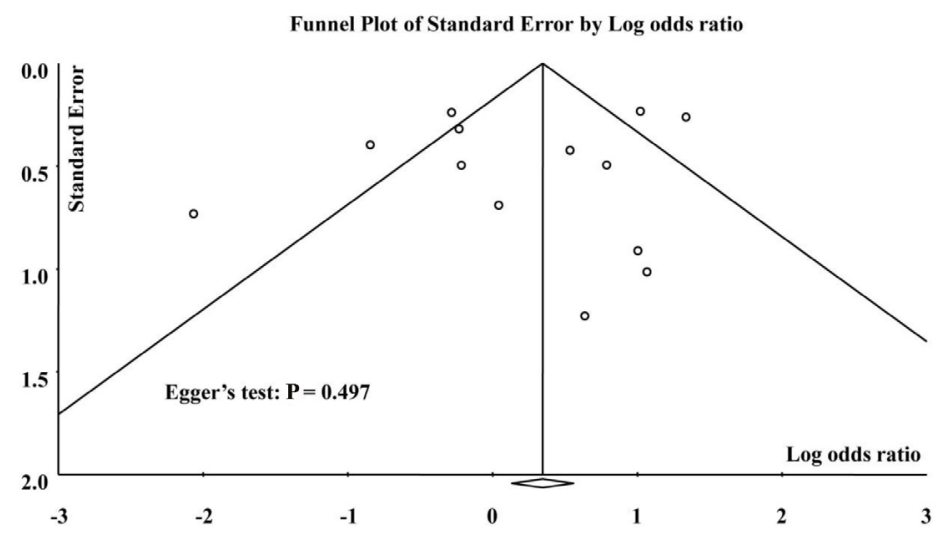

Figure 4. Funnel plot of the results in AA vs GG comparison based on random-effect model.

\section{DISCUSSION}

TNF- $\alpha$ is a multifunctional pro-inflammatory cytokine, and plays a role in the pathogenesis of heart failure (Libby, 2000). Genetic polymorphisms in the TNF- $\alpha$ gene can influence susceptibility to human diseases via modulation of TNF- $\alpha$ expression. G-308A polymorphism is a single nucleotide conversion in the TNF- $\alpha$ promoter at position -308 , which results in nucleotide substitution from guanine (G) to adenine (A) (Falvo et al., 2010). TNF- $\alpha$ induces activation of leukocytes as well as secretion of platelet-activating factors and endothelial adhesion molecules. Therefore, it can significantly affect MI formation and development (Kroeger et al., 1997; Ni and Zhang, 2009; Sprague and Khalil, 2009). Many studies have previously investigated the association between TNF- $\alpha$ G-308A polymorphism and MI risk, but have yielded inconsistent results. Meta-analysis is a useful method to combine various single studies to obtain a larger sample size (Bax et al., 2007; Zeng et al., 2015a), and has been widely used in genetic association studies (Leng et al., 2013; Mao et al., 2013; Yan et al., 2014; Suo et al., 2015; Zeng et al., 2015b). In the present study, we performed a metaanalysis to evaluate the association between TNF- $\alpha$ G-308A polymorphism and MI risk. We included 13 case-control studies with a total of 6037 cases and 7262 controls.

Overall, using the 5 genetic comparison models, results indicated that TNF- $\alpha$ G-308A polymorphism was not associated with MI risk when all 13 studies were pooled into the metaanalysis. Subgroup analyses by ethnicity, source of control, and HWE further showed that there was no association between TNF- $\alpha$ G-308A polymorphism and risk of MI. However, subgroup analysis based on MI stages showed that TNF- $\alpha$ G-308A polymorphism was significantly associated with increased risk of AMI (Table 2).

The major strength of our study is that this is the first meta-analysis conducted on the association between TNF- $\alpha$ G-308A polymorphism and MI risk. We provided a comprehensive assessment of the 13 eligible case-control studies. While the overall results failed to identify a significant association between TNF- $\alpha$ G-308A polymorphism and overall MI risk, this polymorphism was found to be associated with increased risk of AMI. Only three studies categorized MI into different stages such as AMI, and the pooled samples amounted to 1424 cases and 2425 controls. This sample size may not have been large enough to offer conclusive results, and hence the association between TNF- $\alpha$ G-308A polymorphism and the risk of AMI 
should be further investigated in the future with a larger sample size.

Another limitation in our meta-analysis was the substantial heterogeneity found between the studies. Although heterogeneity is very common in genetic association meta-analyses, we cannot ignore it. Subgroup analyses in the current study revealed that the heterogeneity did not arise due to differences in ethnicity, source of control, HWE, or the stages of MI. Inspections of the funnel plots suggested that they were not all symmetrical. This may be due to the fact that sample sizes of many studies included in our meta-analysis were relatively small (Rich, 2006); the number of eligible studies included in total was also not enough. In addition, 3 potential studies in Russia were not included due to publication language and difficulties in accessing Russian databases (Shevchenko et al., 2010; Sudomoina et al., 2010; Konenkov et al., 2012). It is known that there are several polymorphisms associated with MI risk, but the gene-gene interactions were not addressed in our current meta-analysis due to insufficient data. This deficiency also limited our ability to examine gene- environmental interactions. Finally, due to the lack of adjusted data in the reported studies, our meta-analysis was based on unadjusted estimations. Therefore, more studies with adjusted risk factor estimates are needed to obtain a more accurate analysis of this association.

In summary, our meta-analysis suggested that the TNF- $\alpha$ G-308A polymorphism may not be associated with risk of MI based on the currently available data from the general population, but instead may be associated with AMI. However, due to study limitations, better designs, larger sample size, stratified MI stages, and adjusted risk factors need to be included in future studies in order to further evaluate our current findings.

\section{Conflicts of interest}

The authors declare no conflicts of interest.

\section{REFERENCES}

Bax L, Yu LM, Ikeda N and Moons KG (2007). A systematic comparison of software dedicated to meta-analysis of causal studies. BMC Med. Res. Methodol. 7: 40. http://dx.doi.org/10.1186/1471-2288-7-40

Bennet AM, van Maarle MC, Hallqvist J, Morgenstern R, et al. (2006). Association of TNF-alpha serum levels and TNFA promoter polymorphisms with risk of myocardial infarction. Atherosclerosis 187: 408-414. http://dx.doi. org/10.1016/j.atherosclerosis.2005.09.022

Biswas S, Ghoshal PK and Mandal N (2014). Synergistic effect of anti and pro-inflammatory cytokine genes and their promoter polymorphism with ST-elevation of myocardial infarction. Gene 544: 145-151. http://dx.doi.org/10.1016/j. gene.2014.04.065

Cheng K, Zhao YJ, Liu L and Wan JJ (2013). Tumor necrosis factor- $\alpha 238$ G/A polymorphism and risk of hepatocellular carcinoma: evidence from a meta-analysis. Asian Pac. J. Cancer Prev. 14: 3275-3279. http://dx.doi.org/10.7314/ APJCP.2013.14.5.3275

Chu H, Yang J, Mi S, Bhuyan SS, et al. (2012). Tumor necrosis factor-alpha G-308 A polymorphism and risk of coronary heart disease and myocardial infarction: A case-control study and meta-analysis. J. Cardiovasc. Dis. Res. 3: 84-90. http://dx.doi.org/10.4103/0975-3583.95359

Edmondson D, Newman JD, Whang W and Davidson KW (2013). Emotional triggers in myocardial infarction: do they matter? Eur. Heart J. 34: 300-306. http://dx.doi.org/10.1093/eurheartj/ehs398

Falvo JV, Tsytsykova AV and Goldfeld AE (2010). Transcriptional control of the TNF gene. Curr. Dir. Autoimmun. 11: 27-60. http://dx.doi.org/10.1159/000289196

Ghaderian SM, Akbarzadeh Najar R and Tabatabaei Panah AS (2011). Tumor necrosis factor- $\alpha$ : investigation of gene polymorphism and regulation of TACE-TNF- $\alpha$ system in patients with acute myocardial infarction. Mol. Biol. Rep. 38: 4971-4977.http://dx.doi.org/10.1007/s11033-010-0641-x 
Herrmann SM, Ricard S, Nicaud V, Mallet C, et al. (1998). Polymorphisms of the tumour necrosis factor-alpha gene, coronary heart disease and obesity. Eur. J. Clin. Invest. 28: 59-66.http://dx.doi.org/10.1046/j.1365-2362.1998.00244.x

Higgins JP, Thompson SG, Deeks JJ and Altman DG (2003). Measuring inconsistency in meta-analyses. BMJ 327: $557-$ 560. http://dx.doi.org/10.1136/bmj.327.7414.557

Hou L, Huang J, Lu X, Wang L, et al. (2009). Polymorphisms of tumor necrosis factor alpha gene and coronary heart disease in a Chinese Han population: interaction with cigarette smoking. Thromb. Res. 123: 822-826. http://dx.doi. org/10.1016/j.thromres.2008.07.016

Koch W, Kastrati A, Böttiger C, Mehilli J, et al. (2001). Interleukin-10 and tumor necrosis factor gene polymorphisms and risk of coronary artery disease and myocardial infarction. Atherosclerosis 159: 137-144. http://dx.doi.org/10.1016/ $\underline{\mathrm{S} 0021-9150(01) 00467-1}$

Konenkov VI, Shevchenko AV, Prokof'ev VF and Maksimov VN (2012). [Complex of genotypes of cytokines as a genetic factor of risk of development of myocardial infarction of in Europien population of Russia men]. Kardiologiia 52: 22-29.

Kroeger KM, Carville KS and Abraham LJ (1997). The -308 tumor necrosis factor-alpha promoter polymorphism effects transcription. Mol. Immunol. 34: 391-399. http://dx.doi.org/10.1016/S0161-5890(97)00052-7

Leng WD, He MN, Chen QL, Gong H, et al. (2013). Vascular endothelial growth factor (VEGF) gene polymorphisms and risk of head and neck cancer: a meta-analysis involving 2,444 individuals. Mol. Biol. Rep. 40: 5987-5992. http:// dx.doi.org/10.1007/s11033-013-2708-y

Leng WD, Zeng XT, Kwong JS and Hua XP (2015). Periodontal disease and risk of coronary heart disease: An updated metaanalysis of prospective cohort studies. Int. J. Cardiol. 201: 469-472. http://dx.doi.org/10.1016/j.ijcard.2015.07.087

Libby P (2000). Coronary artery injury and the biology of atherosclerosis: inflammation, thrombosis, and stabilization. Am. J.Cardiol.86: 3J-8J; discussion 8J-9J.

Mao M, Zeng XT, Ma T, He W, et al. (2013). Interleukin-1 $\alpha-899(+4845)$ C®T polymorphism increases the risk of chronic periodontitis: evidence from a meta-analysis of 23 case-control studies. Gene 532: 114-119. http://dx.doi. org/10.1016/j.gene.2013.09.043

Marenberg ME, Risch N, Berkman LF, Floderus B, et al. (1994). Genetic susceptibility to death from coronary heart disease in a study of twins. N. Engl. J. Med. 330: 1041-1046. http://dx.doi.org/10.1056/NEJM199404143301503

Meyers DG, Neuberger JS and He J (2009). Cardiovascular effect of bans on smoking in public places: a systematic review and meta-analysis. J. Am. Coll. Cardiol. 54: 1249-1255.http://dx.doi.org/10.1016/j.jacc.2009.07.022

Moher D, Liberati A, Tetzlaff J and Altman DG; PRISMA Group (2009). Preferred reporting items for systematic reviews and meta-analyses: the PRISMA statement. PLOS Med. 6: e1000097.http://dx.doi.org/10.1371/journal. pmed. 1000097

Ni Y and Zhang J (2009). Association of deoxyribonuclease I genetic polymorphisms with myocardial infarction in Han Chinese. Mol. Biol. Rep. 36: 595-601.http://dx.doi.org/10.1007/s11033-008-9218-3

Olivieri F, Antonicelli R, Cardelli M, Marchegiani F, et al. (2006). Genetic polymorphisms of inflammatory cytokines and myocardial infarction in the elderly. Mech. Ageing Dev. 127: 552-559. http://dx.doi.org/10.1016/j.mad.2006.01.013

Padovani JC, Pazin-Filho A, Simões MV, Marin-Neto JA, et al. (2000). Gene polymorphisms in the TNF locus and the risk of myocardial infarction. Thromb. Res. 100: 263-269. http://dx.doi.org/10.1016/S0049-3848(00)00315-7

Rich MW (2006). Epidemiology, clinical features, and prognosis of acute myocardial infarction in the elderly. Am. J. Geriatr. Cardiol. 15: 7-11, quiz 12.http://dx.doi.org/10.1111/j.1076-7460.2006.05273.x

Sattar N (2013). Revisiting the links between glycaemia, diabetes and cardiovascular disease. Diabetologia 56: 686-695. http://dx.doi.org/10.1007/s00125-012-2817-5

Schunkert H, Erdmann J and Samani NJ (2010). Genetics of myocardial infarction: a progress report. Eur. Heart J. 31: 918-925.http://dx.doi.org/10.1093/eurheartj/ehq038

Shevchenko AV, Golovanova OV, Konenkov VI, Tolkacheva OM, et al. (2010). [Analysis of polymorphism of three positions of promoter region of TNF- gene in patients with ischemic heart disease, unstable angina and myocardial infarction]. Kardiologiia 50: 9-14.

Song GG, Choi SJ, Ji JD and Lee YH (2013). Association between tumor necrosis factor- $\alpha$ promoter $-308 \mathrm{~A} / \mathrm{G},-238 \mathrm{~A} / \mathrm{G}$, interleukin-6 -174 G/C and -572 G/C polymorphisms and periodontal disease: a meta-analysis. Mol. Biol. Rep. 40: 5191-5203.http://dx.doi.org/10.1007/s11033-013-2621-4

Sprague AH and Khalil RA (2009). Inflammatory cytokines in vascular dysfunction and vascular disease. Biochem. Pharmacol. 78: 539-552. http://dx.doi.org/10.1016/j.bcp.2009.04.029

Sudomoina MA, Sukhinina TS, Barsova RM, Favorov AV, et al. (2010). [Complex analsis of association of inflammation genes with myocardial infarction]. Mol. Biol. (Mosk.) 44: 463-471.

Suo DW, Hu Q, Chen J, Sun QH, et al. (2015). Association between the C804A polymorphism in the TGF- $\beta$ gene and the risk of myocardial infarction: a meta-analysis. Genet. Mol. Res. 14: 1566-1579. http://dx.doi.org/10.4238/2015. March.6.4 
Szabó GV (2013). The role and importance of gene polymorphisms in the development of atherosclerosis. Interv. Med. Appl. Sci. 5: 46-51. http://dx.doi.org/10.1556/IMAS.5.2013.1.10

Tobin MD, Braund PS, Burton PR, Thompson JR, et al. (2004). Genotypes and haplotypes predisposing to myocardial infarction: a multilocus case-control study. Eur. Heart J. 25: 459-467. http://dx.doi.org/10.1016/j.ehj.2003.11.014

Vaccarino L, Vitale S, Caruso M, Palmeri M, et al. (2013). Myocardial infarction marker levels are influenced by prothrombin and tumor necrosis factor- $\alpha$ gene polymorphisms in young patients. Cytokine $61: 218-222$. http://dx.doi. org/10.1016/j.cyto.2012.09.021

Yan Y, Weng H, Shen ZH, Wu L, et al. (2014). Association between interleukin-4 gene $-590 \mathrm{c} / \mathrm{t},-33 \mathrm{c} / \mathrm{t}$, and 70-basepair polymorphisms and periodontitis susceptibility: a meta-analysis. J. Periodontol. 85: e354-e362. http://dx.doi. org/10.1902/jop.2014.140317

Yatsuya H, Toyoshima H, Yamagishi K, Tamakoshi K, et al.; Japan Arteriosclerosis Longitudinal Study (JALS) group (2010). Body mass index and risk of stroke and myocardial infarction in a relatively lean population: meta-analysis of 16 Japanese cohorts using individual data. Circ Cardiovasc Qual Outcomes 3: 498-505. http://dx.doi.org/10.1161/ CIRCOUTCOMES.109.908517

Zeng X, Zhang Y, Kwong JS, Zhang C, et al. (2015a). The methodological quality assessment tools for preclinical and clinical studies, systematic review and meta-analysis, and clinical practice guideline: a systematic review. J. Evid. Based Med. 8: 2-10. http://dx.doi.org/10.1111/jebm.12141

Zeng XT, Liu DY, Kwong JS, Leng WD, et al. (2015b). Meta-Analysis of Association Between Interleukin-1 $\beta$ C-511T Polymorphism and Chronic Periodontitis Susceptibility. J. Periodontol. 86: 812-819. http://dx.doi.org/10.1902/ jop. 2015.140698

Zeybek U, Toptas B, Karaali ZE, Kendir M, et al. (2011). Effect of TNF- $\alpha$ and IL-1 $\beta$ genetic variants on the development of myocardial infarction in Turkish population. Mol. Biol. Rep. 38: 5453-5457. http://dx.doi.org/10.1007/s11033$\underline{011-0701-\mathrm{x}}$

Zhuang L, Ma W, Cai D, Zhong H, et al. (2013). Associations between tumor necrosis factor- $\alpha$ polymorphisms and risk of psoriasis: a meta-analysis. PLoS One 8: e68827.http://dx.doi.org/10.1371/journal.pone.0068827 